\title{
The Impact of Digitalization and Resources on Gaining Competitive Advantage in International Markets: The Mediating Role of Marketing, Innovation and Learning Capabilities
}

\author{
Yan Yin Lee and Mohammad Falahat
}

\author{
"If all you're trying to do is essentially the same thing as your rivals, then it's unlikely that you'll be \\ very successful." \\ Michael Porter \\ Professor at Harvard Business School
}

\begin{abstract}
International Entrepreneurship as a field of studies depends on digitalization as an essential factor that drives internationalization. Riding on the wave of digitalization, firms can produce and market their products and services globally through digital platforms with reduced costs and time savings. Yet, digitalization as a determinant of competitive advantages for small and medium enterprises in international markets is rarely examined. This study fills the gap by testing the direct and indirect effects of digitalization on enterprise, specifically focusing on price, product, and service advantages in digitalized international markets. Based on the data collected from 143 exporting SME manufacturers in Malaysia, results from our analysis revealed that digitalization has no direct effect on competitive advantage, but rather has strong indirect effects on product and service advantages. Managers and policymakers can thus leverage digitalization to improve their company's internationalization plans according to its intended competitive strategies.
\end{abstract}

\section{Introduction}

This study aims to contribute to an acceleration of small and medium enterprises (SME) internationalization by identifying key determinants of their competitive advantages for internationalization. Resource-based theory (Barney, 1991; Barney et al., 2011) is often used to explain the determinants of international performance (Cavusgil and Knight, 2015; Øyna and Alon, 2018). However, little is known about the resources and capabilities that lead to Malaysian SMEs' competitive advantages in international markets (Falahat et al., 2013; Falahat et al., 2018). In addition to resources and capabilities, international entrepreneurship scholars are also showing increased interest to explore the role of digitalization in SME internationalization through studies of digital platform firms (Ojala et al. 2018; Stallkamp \& Schotter 2018), internet-based companies (Wittkop et al., 2018), ibusiness firms (Brouthers et al., 2018), and high-tech startups (Neubert 2017 \& 2018). While resources and capabilities are fundamental prerequisites for international research exploration, the concepts existed prior to the emergence of digital era (Coviello, Kano, and Liesch 2017; Wittkop et al. 2018). To date, the interaction between digitalization and these fundamental prerequisites has not been sufficiently validated with quantitative evidence (Coviello et al., 2017; Strange \& Zucchella, 2017; Watson et al., 2018). Despite earlier studies that acknowledge the needs for integrating digitalization with a strategic internationalization model, most studies are still qualitative in nature. More quantitative evidence is therefore needed to demonstrate the role of digitalization in SME internationalization studies (Coviello et al., 2017; Knight \& Liesch, 2016; Neubert, 2018; Ojala et al., 2018).

The impacts of digitalization on business models have been well described in case studies (Neubert, 2017 \& 2018). Some businesses that embrace digitalization for internationalization have achieved early and rapid 

International Markets: The Mediating Role of Marketing, Innovation and Learning

\section{Capabilities Yan Yin Lee and Mohammad Falahat}

internationalization (Stallkamp \& Schotter, 2018; Wittkop et al., 2018). Consistent with this understanding, digitalization's role in determining a SME's competitive advantages and its interaction with other factors are crucial for business owners in their planning and decision-making strategies (Dana, 2017; Knight \& Liesch, 2016; Romanello \& Chiarvesio, 2019). It is important to understand the relationships between digitalization, various resources and capabilities that give a firm competitive advantages, in order for SMEs to accelerate their internationalization (Coviello et al., 2017; Neubert, 2018; Wittkop et al., 2018).

The main objective of this study is to examine the impact of digitalization on SMEs, and to develop a model for the determinants of SMEs' competitive advantages in international markets, with specific consideration to digitalization, resources, and capabilities. The study also tests various capabilities as a mediator in the relationship of digitalization, resources, and competitive advantages. Based on the findings, researchers may further explore the role of digitalization and other determinants of competitive advantages in the context of international entrepreneurship. Managers and policymakers should gain a better understanding of how to incorporate digitalization together with other determinants of competitive advantages that enable the company to enter international markets. This will reduce the risk, time, and cost for a company's internationalization process (Neubert, 2017; 2018; Ojala et al., 2018).

\section{Literature Review}

\section{Underlying theories}

Since the 1990s, "born global" theory has often been used to explain the process of SME internationalization (Rennie, 1993). In this study, we refer to both born global and international new venture studies (Oviatt \& McDougall, 1994 \& 1999) through the lens of a resourcebased view (RBV) (Barney, 1991; Grant, 1991) combined with a dynamic capability view (Teece et al., 1997). In these approaches, empirical studies conducted to relate the resources and capabilities for SME internationalization are used as input to develop the research model.

\section{Competitive advantages in international markets}

In this study, competitive advantages refer to whether a firm performs better in price, product, or service advantages, in comparison with its competitors in international markets (Kaleka \& Morgan, 2017). Specifically, price advantage means a firm is at a better position in terms of pricing when it comes to competing with other industry players in their international venture. Product advantage in contrast means that a firm is at a better position in terms of their product design, customization, adaptation, and/or overall quality in comparison with other industry players in their international venture. Additionally, a service advantage refers to a firm that is at a better position in terms of their reliability of service, timeliness of delivery, product accessibility, and/or overall service quality, and customer satisfaction. These three performance measurements are analogous to the concepts of lower cost strategy and differentiation strategy (Porter, 1980), in which differentiation can be studied either as product differentiation or service differentiation.

Among empirical studies in the field of international entrepreneurship, focus has generally been skewed to international performance, while little investigation has been done on competitive advantages in international markets. This study posits that understanding digitalization, resources, capabilities, and competitive advantages provides additional insights for more systematic planning of resource allocation (Grant, 1991). Hence, we were motivated for the present study to operationalize competitive advantages in international markets that reflect the price, product, and service advantage.

\section{Digitalization for competitive advantages in international markets}

As defined by Autio (2017:2), digitalization refers to "the application of digital technologies and infrastructures in business, economy, and society". Firms thus apply different types of digital technologies, such as ecommerce, big data analytics, internet of things, machine learning, additive manufacturing, and others for value creation (Autio et al., 2018; Nambisan, 2017; Strange \& Zucchella, 2018). SME adopts digital technologies such as informediation (Ordanini \& Pol 2001), e-Commerce (Gregory et al., 2007; Gregory et al., 2019), social media (Eggers et al., 2017), and others in their business (Foroudi et al., 2017; Neubert, 2018; Pagani \& Pardo, 2017). Adopting digital technology can directly or indirectly create competitive advantages in the digital economy.

This study posits that fragmented digitalization studies are in line with Grant's $\operatorname{RBV}(1991)$, in which digitalization is a specific resource that contributes to a company's competitive advantage. Thus, the following hypotheses are developed: 

International Markets: The Mediating Role of Marketing, Innovation and Learning

\section{Capabilities Yan Yin Lee and Mohammad Falahat}

H1: Digitalization positively affects competitive advantage (price, product, service) for SMEs in international markets.

\section{Resources for competitive advantages in international markets}

Guided by new venture internationalization studies, we compile key resources (Laanti et al., 2007; Oviatt \& McDougall, 2005; Ruzzier et al., 2006) that are essential for competitive advantages, and conceptualize them as an international resource. We often see three concepts of management characteristics (Madsen \& Servais, 1997; Weerawardena et al., 2007; Zor et al., 2019), international knowledge (Johanson \& Valne, 1977; Rodríguez-Serrano \& Martín-Armario, 2019), and network (Che Senik et al., 2011; Falahat et al., 2015; Freeman \& Cavusgil, 2007) in SME internationalization studies. Based on the empirical studies, resources may directly be related to capability (Fernández-Mesa \& Alegre, 2015; Lu et al., 2010; Monteiro et al., 2017; Weerawardena, 2003), or to international performance (Cao \& Ma, 2009; Kaleka, 2002; Krammer et al., 2018).

Despite the fact that most studies have directly tested international performance based on financial and strategic performance, this study instead intended to provide more insights on competitive advantages in international markets. The discussion in the earlier section leads to the following hypothesis development:

H2: Resources positively affect competitive advantage (price, product, service) for SMEs in international markets.

\section{Capabilities for competitive advantages in international markets}

Grounded on a resource-based view, we see a likely a bundle of capabilities that contributes to international performance (Kaleka, 2002; Leonidou et al., 2011). A bundle's complexity prevents other firms from imitating or transferring the capabilities easily, thus assisting the firm to outperform its competitors. This study compiles key capabilities from SME internationalization studies that are deemed essential nowadays for competitive advantages.

We posit that a firm with strong international capabilities should exhibit advanced innovation capacities in terms of product and innovation process, which they have control over in terms of product specification, quality, and customization. At the same time, the firm should be able to control productivity and production costs in order to meet price flexibility. In addition, a firm with strong capabilities should exhibit strong marketing capacities (Morgan et al., 2004; Morgan et al., 2012) so that they can effectively introduce their product to new markets. In light of the dynamic capability view, firms with strong capabilities should exhibit strong learning capacities (Gassmann \& Keupp, 2007; Grant, 1991; Johanson \& Vahlne, 2009; Teece et al., 1997), where they can always respond to changes in international markets in terms of regulatory, customer, or market requirements. Firms with learning capabilities know how to apply new technology to support product and innovation process (FernándezMesa \& Alegre, 2015; Oura et al., 2016; Raymond et al,, 2013).

Based on empirical studies, capabilities are directly related to competitive advantages (Ahmadi et al., 2014; Kamboj et al., 2015; Weerawardena, 2003). Nevertheless, most studies have directly tested resources and capabilities on international performance without explicitly investigating competitive advantages (Evangelista \& Mac, 2016; Pham et al., 2017; Raymond et al., 2013; Takahashi et al., 2016). This study instead intended to provide more insights on competitive advantages.

Discussion in the earlier sections leads to the following hypothesis development:

H3: International capabilities positively affect competitive advantage (price, product, service) for SMEs in international markets.

\section{Capabilities as mediator for competitive advantages in international markets}

The study of interactions between resources and capabilities is scarce in comparison to study of the direct relationship between resources, capabilities, and competitive advantages (Kaleka, 2002). Nevertheless, there are exceptions. Some scholars have proposed that capabilities often act as a mediator between resources and performance (Lu et al., 2010). Extending from the direct relationship reported in $\mathrm{H} 2$, this study posits that capabilities are a mediator between resources and competitive advantages in international markets.

Although digitalization may be considered separately from resources, it is conjectured to have similar attributes as a resource. Firms utilize digital tools as input to enhance their international capabilities (Neubert, 2018), and subsequently lead to improved international performance (Lee et al., 2019). This assumption is in line with Grant (1991) and other research models (Fernández-Mesa \& Alegre, 2015; Lu et al., 2010; Monteiro et al., 2017; Weerawardena, 2003). 


\section{The Impact of Digitalization and Resources on Gaining Competitive Advantage in} International Markets: The Mediating Role of Marketing, Innovation and Learning

\section{Capabilities Yan Yin Lee and Mohammad Falahat}

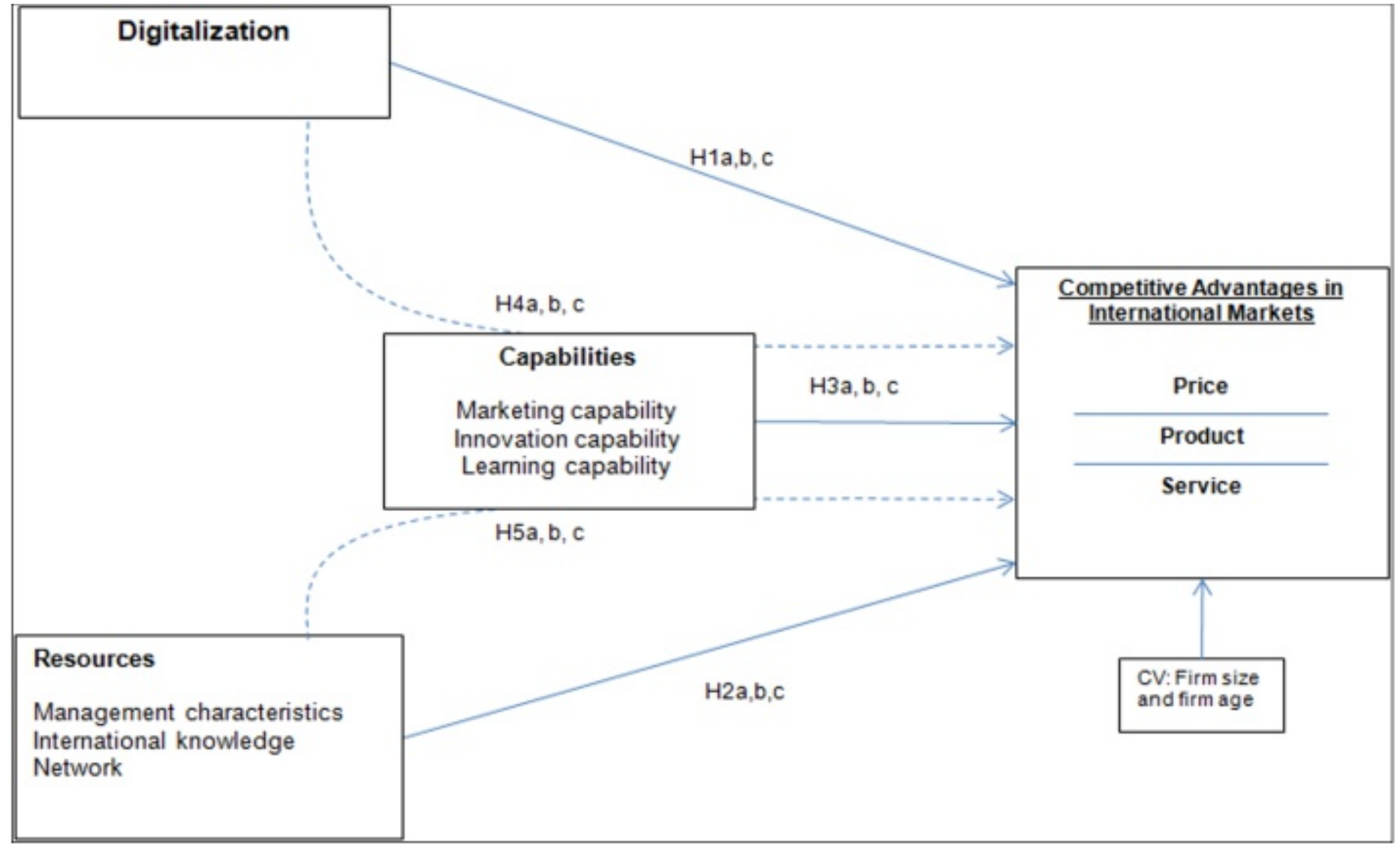

Figure 1. Research model

(Note: Dotted line denotes the indirect relationship, capabilities construct as a mediator)

Thus, the following hypotheses are developed:

H4: International Capabilities mediate the relationship between digitalization and competitive advantage (price, product, service) for SMEs in international markets.

H5: International Capabilities mediate the relationship between resources and competitive advantage (price, product, service) for SMEs in international markets.

The research model is presented in Figure 1.

\section{Research Methods}

Malaysia is considered as a good representative of emerging countries in the world (Bloomberg 2018). Based on key determinants of competitive advantages compiled from SME internationalization literature, this study adopts a quantitative research approach to examine the role of these determinants in the Malaysian context. In addition to a literature review, advice from experts was used as input to further advance a questionnaire related to the main objectives of the research. This gave us extensive information about key determinants associated with competitive advantages for Malaysian firms in international markets.

Manufacturers were selected as the study's sample, due to the fact that their international export business mostly involved manufactured goods. Owing to the type of business, this excluded service providers to ensure homogeneity of the samples, especially in term of resources and capabilities involved in the business process. Thus, the questionnaire was distributed to exporting SMEs from manufacturing sectors.

The MATRADE (Malaysia External Trade Development Corporation) directory was used as the sampling frame. This directory is the most complete and updated directory to reach exporting SME manufacturers, compared with other directories that are not exportfocus. Company selection was derived by using a quota sampling technique. First, a total of 8,869 unique contacts in the directory was categorized according to industry sectors, and a ratio of each sector was calculated. For instance, 2,643 out of 8,869 firms (30\% of 

International Markets: The Mediating Role of Marketing, Innovation and Learning

\section{Capabilities Yan Yin Lee and Mohammad Falahat}

the firms) were from the food and beverage industry. Next, a total of 1,000 SMEs were randomly selected from the directory, according to the calculated ratio. The chosen firms were contacted through email, or called to verify their ongoing activity in an export business, prior to sending the questionnaire.

The survey received 143 usable responses. All responses were screened to ensure they are exporting manufacturers. $41.3 \%$ of the respondents had business operations under 10 years, and $49 \%$ had below 25 employees. Respondents came from multiple industries, the top three being food and beverages (32\%), household and consumer products (15\%), and electrical, electronic, medical, and telecommunications (14\%).

The measurements were adapted from existing literature and all measures used were previously validated in the literature. Sources for measured items are outlined in Appendix 1. All items were measured in a five-point Likert scale. The analysis was carried out using SmartPLS v.3.2.8 software (Ringle et al., 2015).

\section{Results}

A total of 143 responses were received and used for data analysis. Prior to assessing the measurement model, the data was checked for non-response bias and common method bias. Next, the composite reliability and average variance extracted were confirmed within the recommended threshold (Hair et al., 2017). Then, the Heterotrait-monotrait ratio approach (HTMT) was used to assess discriminant validity. All HTMT values are below 0.85 , thus all constructs are distinctive (Henseler et al., 2015).

Resource and capability constructs were developed using repeated indicators approach (Hair et al., 2017). Prior to hypotheses testing, a collinearity test was carried out. VIF values recorded below five, thus there is no critical concern of collinearity (Hair et al., 2017).

\section{Hypotheses testing}

Based on 5,000 samples using a bootstrapping procedure, the significance of the path coefficients of hypothesized relationships was assessed based on pvalues. The beta values and $\mathrm{p}$-values were reported in Table 1. In a PLS-SEM context, bootstrapping is the most recommended approach to test mediating effects (Hair et al., 2017). Table 1 shows the mediator test results, including two control variables and their relationships with competitive advantages. Most of the relationships are not significant, except firm age, which is positively related to service advantage.

The coefficient of determination (R2) represents the amount of variance in the endogenous construct explained by all predictors in the model. Table 2 indicates that exogenous constructs explain 59.6\% variance in price advantage, $42.6 \%$ variance in service advantage, and $33.9 \%$ variance in product advantage. As well, the Stone-Geisser's Q2 values were greater than zero, which indicates the predictive relevance of the model (Hair et al., 2017).

\section{Discussion}

The research objective was to better understand the role of digitalization in achieving competitive advantages for SMEs internationalization. A firm can utilize different types of digital technologies (Pagani \& Pardo, 2017; Strange \& Zucchella, 2017) to enhance their competitive advantages. This study measures digitalization based on the use of digital technologies for learning, sales and marketing, process improvement, and product development, thus covering a wider scope of digitalization instead of focusing on a specific type of digital application (Gregory et al., 2019; Ordanini \& Pol, 2001).

We find that capabilities can be used to mediate digitalization for better product and service advantages. The study also provides an important insight that digitalization has no direct influence on either price, product, or service advantage. A firm should not automatically expect a positive outcome on its international competitive advantages through digitalization, without at the same time considering the roles of other interrelated factors (Neubert, 2018; Ojala et al., 2018). Instead, a firm should aim to develop international capabilities through digitalization, which eventually will lead it to better product and service advantages. The study shows no effect of digitalization on price advantage, in line with other studies that have commented that digitalization is costly, and often unable to yield short term financial gain (Choshin \& Ghaffari, 2017). Overall, the impact of digitalization may not be directly reflected through competitive advantages in international markets. Yet, firms should not ignore the indirect effect of digitalization as an antecedent to ramping up international capabilities.

The study also examined resources associated with competitive advantages for SMEs aiming to internationalize. While resources themselves appear 
The Impact of Digitalization and Resources on Gaining Competitive Advantage in International Markets: The Mediating Role of Marketing, Innovation and Learning Capabilities Yan Yin Lee and Mohammad Falahat

Table 1. Hypotheses testing

\begin{tabular}{|c|c|c|c|c|c|}
\hline \# & Hypotheses & $\begin{array}{l}\text { Path } \\
\text { Coeffici } \\
\text { ent }\end{array}$ & p Value & VIF & Result \\
\hline H1a & Digital -> Price Adv & 0.057 & 0.569 & 2.155 & Not supported \\
\hline $\mathrm{H} 1 \mathrm{~b}$ & Digital $->$ Prod Adv & -0.003 & 0.983 & 2.155 & Not supported \\
\hline $\mathrm{H} 1 \mathrm{c}$ & Digital -> Service Adv & 0.063 & 0.530 & 2.155 & Not supported \\
\hline $\mathrm{H} 2 \mathrm{a}$ & Resource -> Price Adv & 0.714 & $\begin{array}{l}0.000^{*} \\
* *\end{array}$ & 2.149 & Supported \\
\hline $\mathrm{H} 2 \mathrm{~b}$ & Resource $->$ Prod Adv & 0.115 & 0.233 & 2.149 & Not supported \\
\hline $\mathrm{H} 2 \mathrm{c}$ & Resource $->$ Service Adv & 0.031 & 0.741 & 2.149 & Not supported \\
\hline $\mathrm{H} 3 \mathrm{a}$ & Capability -> Price Adv & 0.031 & 0.744 & 2.351 & Not supported \\
\hline $\mathrm{H} 3 \mathrm{~b}$ & Capability -> Prod Adv & 0.503 & $\begin{array}{l}0.000^{*} \\
* *\end{array}$ & 2.351 & Supported \\
\hline $\mathrm{H} 3 \mathrm{c}$ & Capability -> Service Adv & 0.587 & $\begin{array}{l}0.000^{*} \\
* *\end{array}$ & 2.351 & Supported \\
\hline $\mathrm{H} 4 \mathrm{a}$ & $\begin{array}{l}\text { Digital -> Capability -> Price } \\
\text { Adv }\end{array}$ & 0.014 & 0.746 & & Not supported \\
\hline $\mathrm{H} 4 \mathrm{~b}$ & $\begin{array}{l}\text { Digital }->\text { Capability }->\text { Prod } \\
\text { Adv }\end{array}$ & 0.218 & $\begin{array}{l}0.002^{*} \\
* *\end{array}$ & & Supported \\
\hline $\mathrm{H} 4 \mathrm{c}$ & $\begin{array}{l}\text { Digital }->\text { Capability }->\text { Service } \\
\text { Adv }\end{array}$ & 0.255 & $\begin{array}{l}0.000^{*} \\
* *\end{array}$ & & Supported \\
\hline $\mathrm{H} 5 \mathrm{a}$ & $\begin{array}{l}\text { Resource }->\text { Capability }->\text { Price } \\
\text { Adv }\end{array}$ & 0.012 & 0.751 & & Not supported \\
\hline $\mathrm{H} 5 \mathrm{~b}$ & $\begin{array}{l}\text { Resource }->\text { Capability }->\text { Prod } \\
\text { Adv }\end{array}$ & 0.201 & $\begin{array}{l}0.000^{*} \\
* *\end{array}$ & & Supported \\
\hline $\mathrm{H} 5 \mathrm{c}$ & $\begin{array}{l}\text { Resource }->\text { Capability - } \\
>\text { Service Adv }\end{array}$ & 0.234 & $\begin{array}{l}0.000^{*} \\
* *\end{array}$ & & Supported \\
\hline $\mathrm{CV}$ & Firmsize--> PriceAdv & -0.015 & 0.748 & & Insignificant \\
\hline $\mathrm{CV}$ & Firmsize--> ProdAdv & 0.007 & 0.911 & & Insignificant \\
\hline $\mathrm{CV}$ & Firmsize--> ServiceAdv & 0.014 & 0.829 & & Insignificant \\
\hline $\mathrm{CV}$ & Firmage--> PriceAdv & 0.032 & 0.473 & & Insignificant \\
\hline $\mathrm{CV}$ & Firmage--> ProdAdv & 0.075 & 0.231 & & Insignificant \\
\hline $\mathrm{CV}$ & Firmage--> ServiceAdv & 0.148 & $\begin{array}{l}0.009 * \\
* *\end{array}$ & & Significant \\
\hline
\end{tabular}

Note: CV: Control variable 

International Markets: The Mediating Role of Marketing, Innovation and Learning

\section{Capabilities Yan Yin Lee and Mohammad Falahat}

insufficient to yield product and service advantages, they may assist exporting SME manufacturers to gain a better position in international markets with a price advantage. Hypothesis 2 showed that there is a direct relationship between resources and price advantage. This implies that SMEs without strong capabilities can explore international markets if they are able to offer a price advantage compared with their competitors. These SMEs strive to compete with lower costs, and sell with a better price in order to gain market attention. Generally, resources are a strong predictor of price advantage, as shown with a path coefficient in the study of 0.714 and effect size of 0.587 .
The study also examines marketing, innovation and learning capabilities as associated with competitive advantages for SMEs internationalization. Hypothesis 3 reveals that capabilities are not a predictor for price advantage. Firms with strong capabilities may not be competitive in term of their pricing. Nevertheless, they can still compete in international markets through better products or service advantages. This is consistent with prior studies that suggest resource-scarce SMEs mostly compete with niche strategies, instead of cost leadership strategies (Knight \& Liesch, 2016).

\begin{tabular}{lll}
\hline & R Square & Q Square \\
\hline Price Advantage & 0.596 & 0.491 \\
Prod Advantage & 0.339 & 0.174 \\
Service Advantage & 0.426 & 0.266 \\
\hline
\end{tabular}

Table 2. The value of $R$ square and $Q$ square

Apart from having a direct relationship, capabilities also act as a mediator in 'digitalization-competitive advantages' and 'resources-competitive advantages' relationships. Hypotheses 4 and 5 validate the resourcecapability-competitive advantage relationship, consistent with other studies (Lu et al., 2010). In brief, our findings demonstrate the important roles of capabilities, particularly in achieving product and service advantages. Firms are likely to accelerate their internationalization through product and service advantages by developing strong capabilities.

This study empirically tested a model that was developed on the ground of a few well recognized theories for SME internationalization. It thus extends our understanding of network theory, resource-based theory, organisational learning theory, and new venture internationalisation theory. Before this, there were only limited quantitative studies for drivers of SME internationalisation (Gerschewski et al., 2015), particularly empirical studies related to Malaysian SMEs (Falahat et al., 2018). Additionally, the study discussed the role of digitalization for SME internationalisation. Although researchers always highlight the importance of digitalization in the current digital economy, the digitalization construct has rarely been tested in SME internationalisation research model especially in emerging market. This research therefore provides important insights about the role of digitalization, and extends our understanding of the resource-based view in digital economics. It also connects resources and capabilities to three different types of competitive advantages in international markets. In the field of international entrepreneurship, our research helps to close the gap between digitalization, resources, capabilities, and international performance through a better understanding of the outcomes of these variables on price, product, and service advantages. This complements earlier work on international performance, which were consulted and cited throughout our analysis.

Generally, this study discusses the success factors for Malaysian exporting manufacturers who use digital tools. SMEs who wish to explore international markets can evaluate their readiness to internationalize or transnationalize through examining the extent of their resources and capabilities. Subsequently, they can focus their investment by developing resources and capabilities that best suit their business strategy. Apart from resources, firms may also consider digitalization as a mean of enhancing their international capabilities.

The research findings contribute to justifications for the need to adopt digitalization, together with other resources and capabilities for internationalisation. In the real business world, a firm may need to achieve a price advantage, product or service advantage, depending on their operating context. Based on their research findings, managers are aware of the relationships between resources and the capabilities that give different types of competitive advantages. Managers can assess their company resources for potential to achieve price advantages. Similarly, 

International Markets: The Mediating Role of Marketing, Innovation and Learning

\section{Capabilities Yan Yin Lee and Mohammad Falahat}

managers who plan to pursue product and service advantages should enhance their international capabilities. They may in this pursuit cultivate suitable management characteristics, build up network orientation, acquire more international knowledge, and adopt digitalization to achieve greater international capabilities. The ready and suitable use of digital tools is going to accelerate this process.

We recommend that SMEs with comparatively limited resources to sustain in a price war should consider more effective use of digital tools to enhance their marketing, learning. and innovation capabilities. This will enable them to outperform otherwise more resourceful competitors, through uniqueness of service or product.

This study has a few limitations. First, the collected data does not realistically demonstrate the dynamic pattern of the relationships due to it is cross-sectional character. Second, the model intends to focus on firms' internal factors only; thus, the influence of external factors on the model has not been considered. Third, the findings are restricted to manufacturing firms from a single country, which limits the generalizability of the findings.

In the future, researchers may extend the research model to exporters from other industries, such as the service industry, and examine the dynamic pattern of relationships there by employing longitudinal data. It is also essential that future research demonstrate how robust this model is when interacting with important external factors, such as market conditions and government intervention (Knight \& Liesch, 2016).

\section{Conclusion}

This study demonstrates the distinctive roles of digitalization, resources, and capabilities with different types of competitive advantages in international markets. Resources contribute to price advantage, capabilities contribute to product and service advantages, while digitalization has no direct effect on any of these competitive advantages.

Yet, the indirect effects of digitalization and resources on product and service advantages keep these two constructs important in any comprehensive model of determinants for competitive advantages in international markets. These findings shed light on unique mechanisms and antecedents for managers who aim to focus on specific aspects of competitive strategies.

\section{Acknowledgements}

This work was supported by the Malaysia Ministry of Education (MOE) under FRGS scheme (FRGS/1/2017/SS01/UTAR/02/3).

\section{References}

Ahmadi, H., Cass, A. O., and Miles, M. P. 2014. Product Resource - Capability Complementarity, Integration mechanisms, and First Product Advantage. Journal of Business Research, 67(5): 704-709.

Autio, E. 2017. Digitalisation, Ecosystems, Entrepreneurship and Policy. Perspectives into Topical Issues Is Society and Ways to Support Political Decision Making. Government's Analysis, Research and Assessment Activities Policy Brief, 20: 112.

Autio, E., Nambisan, S., Thomas, L. D., and Wright, M. 2018. Digital Affordances, Spatial Affordances, and the Genesis of Entrepreneurial Ecosystems. Strategic Entrepreneurship Journal, 12(1): 72-95.

Barney, J. B. 1991. Firm Resources and Sustained Competitive Advantage. Journal of Management.

Barney, J. B., Ketchen Jr, D. J., and Wright, M. 2011. The Future of Resource-based Theory: Revitalization or Decline? Journal of Management, 37(5): 1299-1315.

Bloomberg 2018. Malaysia Beats Emerging Market Peers as Asia Outshines.

https://www.bloomberg.com/news/articles/2018-11$27 /$ turkey-sinks-to-last-on-emerging-market-

scorecard-malaysia-tops. Accessed on February. 22, 2019.

Brouthers, K. D., Geisser, K. D., and Rothlauf, F. 2016. Explaining the Internationalization of ibusiness Firms. Journal of International Business Studies, 47(5): 513-534.

Cao, C. X., and Ma, H. Y. 2009. Business, Network, and Entrepreneur: The Drivers of Rapid Internationalization of the Born Global Firms. Proceedings - International Conference on Management and Service Science, MASS 2009.

Cavusgil, S. T., and Knight, G. 2009. Born Global Firms: A New International Enterprise. New York: Business Expert Press.

Cavusgil, S. T., and Knight, G. 2015. The Born Global Firm: An Entrepreneurial and Capabilities Perspective on Early and Rapid Internationalization. Journal of International Business Studies, 46(1): 3-16.

Che Senik, Z., Scott-Ladd, B, Entrekin, L and Adham KA. 2011. Networking and Internationalization of SMEs in Emerging Economies. Journal of International Entrepreneurship, 9(4): 259-281. 

International Markets: The Mediating Role of Marketing, Innovation and Learning

\section{Capabilities Yan Yin Lee and Mohammad Falahat}

Choshin, M., and Ghaffari, A. 2017. An Investigation of the Impact of Effective Factors on the Success of Ecommerce in Small- and Medium-sized Companies. Computers in Human Behavior, 66: 67-74.

Coviello, N., Kano, L., and Liesch, P. W. (2017). Adapting the Uppsala Model to a Modern World: Macrocontext and Microfoundations. Journal of International Business Studies, 48(9): 1151-1164.

Dana, L. P. 2017. International entrepreneurship research: how it evolved and directions for the future. International Journal of Entrepreneurship and Small Business, 30(4): 477-489.

Eggers, F., Hatak, I., Kraus, S., and Niemand, T. 2017. Technologies that Support Marketing and Market Development in SMEs: Evidence from Social Networks. Journal of Small Business Management, 55(2): 270-302.

Eriksson, K., Johanson, J., Majkgård, A., \& Sharma, D. D. 1997. Experiential Knowledge and Cost in the Internationalization Process. Journal of International Business Studies, 28(2): 337-360.

Evangelista, F. and Mac, L. 2016. The Influence of Experience and Deliberate Learning on SME Export Performance. International Journal of Entrepreneurial Behavior and Research, 22(6): 860879.

Falahat, M., Knight, G. and Alon, I. 2018. Orientations and Capabilities of Born Global Firms from Emerging Markets. International Marketing Review, (35)6: 936957.

Falahat, M., Migin, M.W., Chong, S.C. and Phang, F.K. 2015. Conceptualising the Early and Rapid Internationalising Firms. 2nd Global Conference on Business and Social Science: Procedia-Social and Behavioral Sciences, 211, Bali, Indonesia: 612-618.

Falahat, M., Mohamad, O. and Migin, M.W. 2013. Born Global Firms in Developing Economies: The Case of Malaysia. Australian Journal of Basic and Applied Sciences, 7(4): 586-594.

Fernández-Mesa, A., and Alegre, J. 2015. Entrepreneurial Orientation and Export Intensity: Examining the Interplay of Organizational Learning and Innovation. International Business Review, 24(1): 148-156.

Foroudi, P., Gupta, S., Nazarian, A. and Duda, M. 2017. Digital Technology and Marketing Management Capability: Achieving Growth in SMEs. Qualitative Market Research: An International Journal, 20(2): 230246.

Freeman, S., and Cavusgil, S. T. 2007. Toward a Typology of Commitment States among Managers of Born-Global Firms: A Study of Accelerated Internationalization. Journal of International Marketing, 15(4): 1-40.

Gassmann, O., and Keupp, M. M. 2007. The Competitive Advantage of Early and Rapidly Internationalising SMEs in the Biotechnology Industry: A Knowledgebased View. Journal of World Business, 42(3): 350-366.
Gerschewski, S., Rose, E. L., \& Lindsay, V. J. 2015. Understanding the Drivers of International Performance for Born Global Firms: An Integrated Perspective. Journal of World Business, 50(3): 558-575.

Grant, R. M. 1991. The Resource-based Theory of Competitive Advantage: Implications for Strategy Formulation. California Management Review, 33(3): 114-135.

Gregory, G., Karavdic, M., and Zou, S. 2007. The Effects of E-commerce Drivers on Export Marketing Strategy. Journal of International Marketing, 15(2): 30-57.

Gregory, G. D., Ngo, L. V., and Karavdic, M. 2019. Developing E-commerce Marketing Capabilities and Efficiencies for Enhanced Performance in Businessto-Business Export Ventures. Industrial Marketing Management, 78: 146-157.

Hair, J.F., Hult, G.T.M., Ringle, C.M. and Sarstedt, M. 2017. A Primer on Partial Least Squares Q6 Structural Equation Modeling (PLS-SEM). Sage Publications.

Hao, S., \& Song, M. 2016. Technology-driven Strategy and Firm Performance: Are Strategic Capabilities Missing Links? Journal of Business Research, 69(2): 751-759.

Henseler, J., Ringle, C. M., and Sarstedt, M. 2015. A New Criterion for Assessing Discriminant Validity in Variance-based Structural Equation Modeling. Journal of the Academy of Marketing Science, 43(1): 115-135.

Johanson, J. and Vahlne, J.E. 1977. The Internationalization Process of the Firm - A Model of Knowledge Development and Increasing Foreign Market Commitments. Journal of International Business Studies, 8 (1): 23-32.

Johanson, J., and Vahlne, J. E. 2009. The Uppsala Internationalization Process Model Revisited: From Liability of Foreignness to Liability of Outsidership. Journal of International Business Studies: 1-22.

Kaleka, A. 2002. Resources and Capabilities Driving Competitive Advantage in Export Markets: Guidelines for Industrial Exporters. Industrial Marketing Management, 31(3): 273-283.

Kaleka, A. and Morgan, N.A. 2017. Which Competitive Advantage(s)? Competitive Advantage-Market Performance Relationships in International Markets. Journal of International Marketing, 25(4): 25-49.

Kamboj, S., Goyal, P., and Rahman, Z. 2015. A Resourcebased View on Marketing Capability, Operations Capability and Financial Performance: An Empirical Examination of Mediating Role. Procedia-Social and Behavioral Sciences, 189: 406-415.

Knight, G. A., and Cavusgil, S. T. 2004. Innovation, Organizational Capabilities, and the Born-Global Firm. Journal of International Business Studies, 35(2): 124-141.

Knight, G. A., and Liesch, P. W. 2016. Internationalization: From Incremental to Born Global. Journal of World Business, 51(1): 93-102. 
Krammer, S. M. S., Strange, R., and Lashitew, A. 2018. The Export Performance of Emerging Economy Firms: The Influence of Firm Capabilities and Institutional Environments. International Business Review, 27(1): 218-230.

Laanti, R., Gabrielsson, M., and Gabrielsson, P. 2007. The Globalization Strategies of Business-to-Business Born Global Firms in the Wireless Technology Industry. Industrial Marketing Management, 36(8): 1104-1117.

Lee, Y. Y., Falahat, M., and Sia, B. K. 2019. Impact of Digitalization on the Speed of Internationalization. International Business Research, 12(4): 1-11.

Leonidou, L. C., Palihawadana, D., and Theodosiou, M. 2011. National Export-Promotion Programs as Drivers of Organizational Resources and Capabilities: Effects on Strategy, Competitive Advantage, and Performance. Journal of International Marketing, 19(2): 1-29.

Lu, Y., Zhou, L., Bruton, G., and Li, W. 2010. Capabilities as a Mediator Linking Resources and the International Performance of Entrepreneurial Firms in an Emerging Economy. Journal of International Business Studies, 41(3): 419-436.

Madsen, T. K., and Servais, P. 1997. The Internationalization of Born Globals: An Evolutionary Process? International Business Review, 6(6): 561-583.

Monteiro, A. P., Soares, A. M., and Rua, O. L. 2017. Linking Intangible Resources and Export Performance. Baltic Journal of Management, 12(3): 329-347.

Morgan, N. A, Kaleka, A., and Katsikeas, C. S. 2004. Antecedents of Export Venture Performance: A Theoretical Model and Empirical Assessment. Journal of Marketing, 68(1): 90-108.

Morgan, N. A., Katsikeas, C. S., and Vorhies, D. W. 2012. Export Marketing Strategy Implementation, Export Marketing Capabilities, and Export Venture Performance. Journal of the Academy of Marketing Science, 40(2): 271-289.

Morgan-Thomas, A. and Bridgewater, S. 2004. Internet and Exporting: Determinants of Success in Virtual Export Channels. International Marketing Review, 21(4/5): 393-408.

Nambisan, S. 2017. Digital Entrepreneurship: Toward a Digital Technology Perspective of Entrepreneurship. Entrepreneurship Theory and Practice, 41(6): 10291055.

Neubert, M. 2017. Lean Internationalization: How to Globalize Early and Fast in a Small Economy. Technology Innovation Management Review, 7(5).

Neubert, M. 2018. The Impact of Digitalization on the Speed of Internationalization of Lean Global Startups. Technology Innovation Management Review, 8(5): 44-54.

Ojala, A., Evers, N., and Rialp, A. 2018. Extending the International New Venture Phenomenon to Digital
Platform Providers: A Longitudinal Case Study. Journal of World Business, 53(5): 725-739.

Ordanini, A., and Pol, A. 2001. Infomediation and Competitive Advantage in B2B Digital Marketplaces. European Management Journal, 19(3): 276-285.

Oura, M. M., Zilber, S. N., and Lopes, E. L. 2016. Innovation Capacity, International Experience and Export Performance of SMEs in Brazil. International Business Review, 25(4): 921-932.

Oviatt, B. M., and McDougall, P. P. 1994. Toward a Theory of International New ventures. Journal of International Business Studies, 25(1): 45-64.

Oviatt, B. M., and McDougall, P. P. 1999. A Framework for Understanding Accelerated International Entrepreneurship. Research in Global Strategic Management, 7: 23-40.

Oviatt, B. M., and McDougall, P. P. 2005. Defining International Entrepreneurship and Modeling the Speed of Internationalization. Entrepreneurship Theory and Practice, 29(5): 537-553.

Øyna, S. and Alon, I. 2018. A Review of Born globals. International Studies of Management and Organization, 48(2): 157-180.

Pagani, M., and Pardo, C. 2017. The Impact of Digital Technology on Relationships in a Business Network. Industrial Marketing Management, 67 (May): 185-192.

Pham, T. S. H., Monkhouse, L. Le, and Barnes, B. R. 2017. The Influence of Relational Capability and Marketing Capabilities on the Export Performance of Emerging Market Firms. International Marketing Review, 34(5): 606-628.

Porter, M. E. 1980. Competitive Strategy: Techniques for Analyzing Industries and Companies. (1st ed). Free Press, New York.

Raymond, L., Bergeron, F., and Croteau, A.M. 2013. Innovation Capability and Performance of Manufacturing SMEs: The Paradoxical Effect of IT Integration. Journal of Organizational Computing and Electronic Commerce, 23(3): 249-272.

Rennie, M. W. 1993. Born global. The McKinsey Quarterly, 4: 45-53.

Ringle, C. M., Wende, S., and Becker, J.M. 2015. SmartPLS 3. Boenningstedt: SmartPLS GmbH. http://www.smartpls.com

Rodríguez-Serrano, M. Á., and Martín-Armario, E. 2019. Born Global SMEs, Performance, and Dynamic Absorptive Capacity: Evidence from Spanish Firms. Journal of Small Business Management, 57(2): 298326.

Romanello, R., and Chiarvesio, M. 2019. Early internationalizing firms: 2004-2018. Journal of International Entrepreneurship: 1-48.

Ruzzier, M., Hisrich, R. D., and Antoncic, B. 2006. SME Internationalization Research: Past, Present, and Future. Journal of Small Business and Enterprise Development, 13(4): 476-497. 


\section{Capabilities Yan Yin Lee and Mohammad Falahat}

Song, M., Nason, R. W., and Di Benedetto, C. A. 2008. Distinctive Marketing and Information Technology Capabilities and Strategic Types: A Cross-national Investigation. Journal of International Marketing, 16(1): 4-38.

Stallkamp, M., and Schotter, A. P. 2018. Platforms Without Borders? The International Strategies of Digital Platform Firms. Global Strategy Journal: 1-23.

Strange, R., and Zucchella, A. 2017. Industry 4.0, Global Value Chains and International Business. Multinational Business Review, 25(3): 174-184.

Takahashi, A., Bulgacov, S., Semprebon, E., and Giacomini, M. 2016. Dynamic Capabilities, Marketing Capability and Organizational Performance. Brazilian Business Review, 14(5): 466-478.

Teece, D., Pisano, G., and Shuen, A. 1997. Dynamic Capabilities and Strategic Management. Strategic Management Journal, 18(7): 509-533.

Watson, G., Weaven, S., Perkins, H., Sardana, D., and Palmatier, R. 2018. International Market Entry Strategies: Relational, Digital, and Hybrid Approaches. Journal of International Marketing, 26(1): 30-60.

Weerawardena, J. 2003. The Role of Marketing Capability in Innovation-based Competitive Strategy. Journal of Strategic Marketing, 11(1).

Weerawardena, J., Mort, G. S., Liesch, P. W., and Knight, G. 2007. Conceptualizing Accelerated Internationalization in the Born Global Firm: A Dynamic Capabilities Perspective. Journal of World Business, 42(3): 294-306.

Wittkop, A., Zulauf, K., and Wagner, R. 2018. How Digitalization Changes the Internationalization of Entrepreneurial Firms: Theoretical Considerations and Empirical Evidence. Management Dynamics in the Knowledge Economy, 6(2): 193-207.

Yiu, D. W., Lau, C., \& Bruton, G. D. 2007. International Venturing by Emerging Economy Firms: The Effects of Firm Capabilities, Home Country Networks, and Corporate Entrepreneurship. Journal of International Business Studies, 38(4): 519-540.

Yu, W., Jacobs, M. A., Chavez, R., \& Feng, M. 2017. The Impacts of IT Capability and Marketing Capability on Supply Chain Integration: A Resource-based Perspective. International Journal of Production Research, 55(14): 4196-4211.

Zhang, M., Sarker, S. and Sarker, S. 2013. Drivers and Export Performance Impacts of IT Capability in 'Born Global'Firms: A cross National Study. Information Systems Journal, 23(5): 419-443.

Zor, U., Linder, S., and Endenich, C. 2019. CEO Characteristics and Budgeting Practices in Emerging Market SMEs. Journal of Small Business Management, 57(2): 658-678.

\section{About the Authors}

Yan Yin Lee is a scholarship recipient funded by Malaysia's Ministry of Education (MoE) under FRGS scheme (FRGS/1/2017/SS01/UTAR/02/3) at the Faculty of Accountancy and Management (FAM), Universiti Tunku Abdul Rahman (UTAR), Sungai Long campus, Malaysia. She received the Best Graduate Award in the School of Applied Physics from the Universiti Sains Malaysia (USM), majoring in Applied Physics and minoring in Management Studies. She has been a Senior Management Consultant and trainer in Quality and Environmental Management Systems for over ten years and has consulted more than 100 companies from various industries. She is currently pursuing her Masters of Philosophy. Her research interests include SME internationalisation, SME digitalization, and government support programs.

Mohammad Falahat is currently at the Faculty of Accountancy and Management (FAM), Universiti Tunku Abdul Rahman (UTAR), Sungai Long campus, Malaysia. He is the Chairperson for the Centre for Sustainable Development and Corporate Social Responsibility (CSDCSR) in Business at UTAR. He was awarded a grant to conduct research in the field of International Entrepreneurship by Malaysia's Ministry of Education (MoE) under FRGS scheme (FRGS/1/2017/SS01/UTAR/02/3). He holds a Doctorate of Business Administration from Universiti Sains Malaysia (USM) where he received a Gold Medal Award for the Best Doctor of Business Administration. His interests cover SMEs internationalisation, International Entrepreneurship, business strategies, and born global. His academic work has been presented at international conferences as well as published in reviewed journals and books.

Citation: Lee, Y.Y. and Falahat, M. 2019. The Impact of Digitalization and Resources on Gaining Competitive Advantage in International Markets: Mediating Role of Marketing, Innovation and Learning Capabilities. Technology Innovation Management Review, 9(11): 26-38. http://doi.org/10.22215/timreview/1281

(cc) BY

Keywords: International Entrepreneurship, Digitalization, Competitive advantage, Innovation, Marketing, Learning Capabilities, SMEs 
The Impact of Digitalization and Resources on Gaining Competitive Advantage in International Markets: The Mediating Role of Marketing, Innovation and Learning Capabilities Yan Yin Lee and Mohammad Falahat

Appendix: Descriptive Statistics

\begin{tabular}{|c|c|c|c|c|}
\hline Constructs & & $\begin{array}{l}\text { Outer } \\
\text { Loading }\end{array}$ & CR & AVE \\
\hline Resources ( Reflective second order construct) & & & 0.826 & 0.615 \\
\hline Management characteristics & Mgmt1 & 0.640 & 0.922 & 0.573 \\
\hline \multirow{8}{*}{$\begin{array}{l}\text { Source: Adapted from Knight and Cavusgil (2004); Zhang, } \\
\text { Sarker and Sarker (2013); Pre-test }\end{array}$} & Mgmt2 & 0.779 & & \\
\hline & Mgmt3 & 0.805 & & \\
\hline & Mgmt4 & 0.547 & & \\
\hline & Mgmt5 & 0.838 & & \\
\hline & Mgmt6 & 0.831 & & \\
\hline & Mgmt7 & 0.777 & & \\
\hline & Mgmt8 & 0.760 & & \\
\hline & Mgmt9 & 0.785 & & \\
\hline International Knowledge & IK1 & 0.843 & 0.920 & 0.794 \\
\hline \multirow{2}{*}{$\begin{array}{l}\text { Source: Adapted from Eriksson, Johanson, Majkgard, and } \\
\text { Sharma (1997); Monteiro, Soares, and Rua (2017) }\end{array}$} & IK2 & 0.903 & & \\
\hline & IK3 & 0.925 & & \\
\hline Network & Netw1 & 0.778 & 0.881 & 0.553 \\
\hline \multirow{5}{*}{$\begin{array}{l}\text { Source: Adapted from Falahat et al.(2018); Yiu, Lau, and } \\
\text { Bruton (2007); Pre-test }\end{array}$} & Netw2 & 0.758 & & \\
\hline & Netw3 & 0.778 & & \\
\hline & Netw4 & 0.679 & & \\
\hline & Netw5 & 0.795 & & \\
\hline & Netw6 & 0.664 & & \\
\hline Digitalization & Digital 1 & 0.864 & 0.938 & 0.716 \\
\hline \multirow{5}{*}{$\begin{array}{l}\text { Source: Adapted from Hao and Song (2016); Song, Nason, } \\
\text { and Di Benedetto (2008); Yu, Jacobs, Chavez, and Feng } \\
\text { (2017) }\end{array}$} & Digital 2 & 0.896 & & \\
\hline & Digital 3 & 0.841 & & \\
\hline & Digital 4 & 0.873 & & \\
\hline & Digital 5 & 0.776 & & \\
\hline & Digital 6 & 0.824 & & \\
\hline
\end{tabular}


The Impact of Digitalization and Resources on Gaining Competitive Advantage in International Markets: The Mediating Role of Marketing, Innovation and Learning Capabilities Yan Yin Lee and Mohammad Falahat

\begin{tabular}{|c|c|c|c|c|}
\hline Constructs & & $\begin{array}{c}\text { Outer } \\
\text { Loading }\end{array}$ & CR & AVE \\
\hline \multicolumn{3}{|l|}{ Capabilities ( Reflective second order construct) } & 0.942 & 0.843 \\
\hline Learning capability & LearnCap1 & 0.882 & 0.959 & 0.826 \\
\hline \multirow[t]{4}{*}{ Source: Adapted from Pham et al. (2017) } & LearnCap2 & 0.927 & & \\
\hline & LearnCap3 & 0.910 & & \\
\hline & LearnCap4 & 0.921 & & \\
\hline & LearnCap5 & 0.901 & & \\
\hline Marketing capability & MktCap1 & 0.960 & 0.947 & 0.914 \\
\hline \multirow[t]{3}{*}{ Source: Adapted from Pham et al. (2017) } & MktCap2 & 0.959 & & \\
\hline & MktCap3 & 0.959 & & \\
\hline & MktCap4 & 0.946 & & \\
\hline Innovation capability & InvCap1 & 0.827 & 0.977 & 0.719 \\
\hline \multirow[t]{6}{*}{ Source: Adapted from Pham et al. (2017) } & InvCap2 & 0.837 & & \\
\hline & InvCap3 & 0.857 & & \\
\hline & InvCap4 & 0.859 & & \\
\hline & InvCap5 & 0.834 & & \\
\hline & InvCap6 & 0.864 & & \\
\hline & InvCap7 & 0.854 & & \\
\hline \multirow[t]{2}{*}{ Price advantage } & PriceAdv1 & 0.927 & 0.938 & 0.883 \\
\hline & PriceAdv2 & 0.952 & & \\
\hline \multirow[t]{3}{*}{ Product advantage } & ProdAdv1 & 0.794 & 0.834 & 0.626 \\
\hline & ProdAdv2 & 0.788 & & \\
\hline & ProdAdv3 & 0.792 & & \\
\hline \multirow[t]{2}{*}{ Service advantage } & ServiceAdv1 & 0.774 & 0.918 & 0.691 \\
\hline & ServiceAdv2 & 0.847 & & \\
\hline \multirow[t]{3}{*}{ Source: Adapted from Kaleka and Morgan (2017) } & ServiceAdv3 & 0.807 & & \\
\hline & ServiceAdv 4 & 0.846 & & \\
\hline & ServiceAdv5 & 0.879 & & \\
\hline
\end{tabular}

